\title{
HUBUNGAN EFIKASI DIRI DENGAN KEPATUHAN MELAKUKAN LATIHAN FISIK PADA PASIEN DIABETES MELLITUS TIPE 2
}

\author{
Mia Widha Anindita, Noor Diani, Ifa Hafifah \\ Program Studi Ilmu Keperawatan, Fakultas Kedokteran, Universitas Lambung Mangkurat, Jl. A. Yani KM. 36 Banjarbaru, 70714
}

Correspondence author:

Mia Widha Anindita

Program Studi Ilmu Keperawatan, Fakultas Kedokteran, Universitas Lambung Mangkurat, Jl. A. Yani KM. 36 Banjarbaru, 70714

Email: aqilla22@gmail.com

\section{Article Info:}

Received: 22 January 2019

Revised: 17 June 2019

Accepted: 23 June 2019

Available online: 31 July 2019

Keywords: DM type 2, self efficacy, adherence to physical exercises

DOI: $10.20956 /$ nmsj.v4i1.5956

\begin{abstract}
Introduction: Diabetes mellitus is a chronic disease, and type $2 \mathrm{DM}$ accounts for $90-95 \%$ of total diabetes. Adherence to implementation of physical exercise is very necessary for patients with DM. Self efficacy in diabetic patients can improve the adherence for medications and success to control the sugar levels. Methods: We aimed to analyze the correlation between self efficacy and adherence to physical exercises in type 2 diabetes patients. This is a descriptive cross-sectional study with purposive sampling method. In total, we recruit 60 respondents during December 2018. We used two types of questionnires: self efficacy and adherence to physical exercises to measure the variable of interest. Result: We found that there was a correlation between self efficacy and adherence to physical exercises in type 2 diabetic patients $(p<0.001)$.

Conclusion: Appropriate self efficacy could improve patients' adherence to manage the advised physical examination.
\end{abstract}

\section{PENDAHULUAN}

Diabetes Mellitus (DM) atau yang lebih dikenal masyarakat dengan istilah diabetes, merupakan sekelompok penyakit metabolik yang dikarakteristikan dengan hiperglikemia yang terjadi karena adanya gangguan pada sekresi insulin, kerja insulin, atau kedua-duanya1. DM terjadi ketika tubuh tidak dapat menghasilkan cukup hormon insulin atau tidak dapat menggunakan insulin secara efektif, insulin tersebut bertindak sebagai kunci yang memungkinkan sel tubuh untuk menyerap glukosa dan menggunakannya sebagai energi2.

Secara klinis DM memiliki dua tipe yaitu: tipe 1 dan tipe 2. DM tipe 1 disebabkan karena kurangnya produksi insulin secara absolut akibat proses autoimun, sedangkan DM tipe 2 merupakan kasus terbanyak (90-95\% dari seluruh kasus). DM tipe 2 berlangsung lambat dan progresif, sehingga tidak terdeteksi sejak dini karena gejala yang dialami pasien sering bersifat ringan seperti kelelahan, iritabilitas, poliuria, polidipsi dan luka yang lama sembuh3. DM tipe 2 ini disebabkan berbagai faktor diantaranya: faktor genetik, faktor demografi (kepadatan penduduk, urbanisasi, usia di atas 40 tahun) dan faktor perubahan gaya hidup yang menyebabkan obesitas karena makan berlebih dan hidup santai atau kurang beraktivitas 4 .

Pada tahun 2013, terdapat 382 juta orang yang hidup dengan diabetes di dunia dan 316 juta orang dengan toleransi glukosa terganggu yang berisiko tinggi terhadap penyakit ini, sehingga dikhawatirkan pada tahun 2035 penderita diabetes dapat mencapai 471 juta2. Di Indonesia sendiri terjadi peningkatan jumlah penderita diabetes dari $1,1 \%$ pada tahun 2007 menjadi $2,1 \%$ pada tahun 2013 dan prevalensi DM di wilayah Kalimantan Selatan sebesar $1 \%$ (rentang 0,3-1,7\%)5. 
Berdasarkan data dari Dinas Kesehatan Kota Banjarbaru tahun 2017, jumlah kunjungan pertama penderita DM sebanyak 1081, sedangkan khusus di puskesmas Cempaka, sebanyak 308 kunjungan rawat jalan berulang pasien DM tercatat sejak Januari sampai Agustus 2018.

DM merupakan penyakit menahun yang akan disandang seumur hidup, dan penatalaksanaannya terdiri atas terapi gizi medis, intervensi farmakologis, edukasi dan latihan fisik6. Latihan fisik dapat meningkatkan sensitivitas insulin, memfasilitasi penyerapan glukosa, membantu pengendalian tekanan darah, menurunkan angka kematian dan meningkatkan kualitas hidup6. Pengelolaan penyakit ini sangat memerlukan peran serta dari dokter, perawat, ahli gizi dan tenaga kesehatan lain6. Perawat sebagai edukator sangat berperan dalam memberikan informasi yang tepat pada pasien DM tentang penyakit, pencegahan, komplikasi, pengobatan, dan pengelolaan penyakit ini, termasuk didalamnya meningkatkan efikasi diri7. Efikasi diri adalah keyakinan yang dimiliki individu mengenai kemampuannya untuk mengorganisasi dan menyelesaikan suatu tugas yang diperlukan guna mencapai hasil tertentu8. Efikasi diri memiliki keefektifan yaitu individu mampu menilai dirinya memiliki kekuatan untuk menghasilkan sesuatu yang diinginkan9. Efikasi diri mendorong proses kontrol diri untuk mempertahankan perilaku yang dibutuhkan dalam mengelola perawatan diri atau terapi pada pasien DM10.

Penelitian sebelumnya menunjukkan bahwa masih banyak pasien DM yang tidak patuh dalam melakukan latihan fisik,11 sedangkan efikasi diri pada pengobatan DM dapat meningkatkan kepatuhan dan pencapaian untuk mengontrol kadar gula darah12. Berdasarkan studi terdahulu, didapatkan bahwa penderita DM tipe 2 memiliki efikasi diri yang kurang baik, seperti kurang mampu untuk melakukan latihan fisik sesuai yang dianjurkan oleh dokter, mengikuti pola makan sehat ketika berada diluar rumah, dan minum obat secara teratur. Selain itu, mereka tidak patuh dalam melaksanakan latihan fisik dengan alasan cepat merasa lelah dan terkadang malas.

Melihat pentingnya efikasi diri dalam penatalaksanaan DM, serta kurangnya penelitian pada topik ini, maka peneliti tertarik untuk memeriksa hubungan antara efikasi diri dengan kepatuhan melakukan latihan fisik pada pasien DM tipe 2.

\section{METODE PENELITIAN}

Penelitian menggunakan rancangan deskriptif, dengan metode cross sectional. Teknik sampling yang digunakan dalam penelitian ini adalah non probability sampling, khususnya purposive sampling dengan total 60 responden. Kriteria inklusi pada penelitian ini yaitu pasien DM yang telah terpapar pengetahuan mengenai latihan fisik, dapat berkomunikasi lisan dengan baik, mengerti bahasa Indonesia atau bahasa Banjar, dan bersedia menjadi responden penelitian, sedangkan kriteria eksklusi yaitu responden dengan amputasi kaki dan responden dengan penurunan kesadaran.

Variabel independen dalam penelitian ini adalah efikasi diri, dan variabel dependen adalah kepatuhan melakukan latihan fisik. Data demografi terdiri atas umur, jenis kelamin, pendidikan, pekerjaan, penghasilan per bulan, dan lama menderita DM.

Penelitian ini dilakukan pada Desember 2018 di Kelurahan Cempaka. Instrumen yang digunakan adalah kuesioner yang meliputi karakteristik demografi, efikasi diri,25,26 dan kepatuhan melakukan latihan fisik20. Uji statistik yang digunakan adalah chi-square dengan nilai $\alpha<0.05$. Seluruh analisis menggunakan SPSS versi 25. Persetujuan etik diperoleh dari Fakultas Kedokteran Universitas Lambung Mangkurat dengan nomor surat

No.1067/KEPKFKUNLAM/EC/XII/2017.

\section{HASIL DAN PEMBAHASAN}

\section{Karakteristik Responden}

Tabel 1. Distribusi Usia Responden $(\mathrm{n}=60)$

\begin{tabular}{lccccc}
\hline Variabel & Mean & Median & SD & Min & Max \\
\hline Usia & 53,68 & 53 & 6,926 & 42 & 74 \\
\hline
\end{tabular}

Tabel 1 menunjukkan karakteristik demografis, dimana rata-rata usia responden yaitu 53,62 tahun, dengan usia terendah 42 tahun dan tertinggi 74 tahun. Risiko terkena DM akan meningkat dengan bertambahnya usia, terutama di atas 40 tahun, dan hal ini paling sering terjadi pada DM tipe $2^{13}$. Pada sebagian besar penderita DM tipe 2, penyakit yang dideritanya ini ditemukan secara tidak sengaja ${ }^{3}$. Sesuai pernyataan responden bahwa mereka tidak mengetahui menderita DM tipe 2 dan hal tersebut didapatkan ketika mereka menjalani pemeriksaan gula darah saat petugas puskesmas berkunjung ke rumah mereka. 
Tabel 2. Distribusi Frekuensi Responden

Berdasarkan Karakteristik Jenis Kelamin, Pendidikan , Pekerjaan, Penghasilan per Bulan dan Lama Menderita DM ( $\mathrm{n}=60)$

\begin{tabular}{lcc}
\hline \multicolumn{1}{c}{ Karakteristik } & $\begin{array}{c}\text { Frekuensi } \\
\text { Responden }\end{array}$ & Persentase (\%) \\
\hline Jenis Kelamin & 18 & 30,0 \\
Laki-laki & 42 & 70,0 \\
Perempuan & 60 & 100 \\
\hline Total & & \\
\hline Pendidikan & 16 & 26,7 \\
Tidak tamat & 28 & 46,7 \\
SD & 8 & 13,3 \\
SMP & 5 & 8,3 \\
SMA & 3 & 5,0 \\
PT & 60 & 100 \\
\hline Total & & \\
\hline Pekerjaan & 35 & 58,3 \\
Tidak bekerja & 10 & 16,7 \\
Wiraswasta & 1 & 1,7 \\
PNS/TNI/POL & 14 & 23,3 \\
Lain-lain & 60 & 100 \\
\hline Total & & \\
\hline Penghasilan & 15 & 25,0 \\
Tinggi & 45 & 75,0 \\
Rendah & 60 & 100 \\
\hline Total & & \\
\hline Lama menderita & 39 & 65,0 \\
$<5$ tahun & 21 & 35,0 \\
\hline × tahun & 60 & 100 \\
\hline Total & & \\
\hline
\end{tabular}

Berdasarkan hasil penelitian pada karakteristik responden sesuai dengan tabel 2, menunjukkan responden yang berjenis kelamin perempuan yaitu 42 responden $(70,0 \%)$ lebih banyak dibandingkan responden yang berjenis kelamin laki-laki yaitu 18 responden $(30,0 \%)$. Perempuan memiliki LDL atau kolesterol jahat tingkat trigliseria yang lebih tinggi dibandingkan laki-laki dan memiliki peluang lebih besar dalam peningkatan indeks massa tubuh sehingga prevalensi menderita DM pada perempuan lebih tinggi daripada laki-laki ${ }^{14}$.

Dari tabel 2, didapatkan juga bahwa sebagian besar pendidikan terakhir responden yaitu SD/MI sebanyak 28 responden $(46,7 \%)$. Hasil penelitian oleh Nurhayani (2016) menyatakan bahwa DM lebih banyak dialami oleh responden dengan pendidikan SD. Sejalan dengan hal tersebut, penelitian yang dilakukan oleh Sa'adah (2016) juga memaparkan bahwa dari 48 responden, $19(39,6 \%)$ diantaranya berpendidikan SD. Kami juga menemukan bahwa sebagian besar responden tidak bekerja atau ibu rumah tangga, yaitu sebanyak 35 responden $(58,3 \%)$. Hal ini sejalan dengan hasil penelitian lain yang dilakukan di poliklinik penyakit dalam RSUD Dr.
Abdoer Rahem Situbondo, yang menyatakan bahwa sebagian besar penderita DM (20 responden) tidak bekerja atau ibu rumah tangga. Seseorang yang tidak bekerja cenderung kurang menggerakkan badannya dan kurang berolahraga, sehingga sel-sel tubuh menjadi kurang sensitif terhadap insulin dan peredaran darah tidak lancar. $\mathrm{Hal}$ ini akan meningkat risiko terjadinya DM tipe $2^{13}$.

Berdasarkan penelitian ini, kami menemukan bahwa kebanyakan penderita DM memiliki penghasilan rendah atau di bawah Upah Minimum Provinsi (UMP) Kota Banjarbaru tahun 2018. Status sosial ekonomi diartikan sebagai status sosial dari individu atau kelompok yang diukur melalui kombinasi antara pendapatan, pekerjaan dan pendidikan. Status sosial ekonomi yang rendah akan mempengaruhi kondisi diabetes karena keterbatasan biaya dalam mengakses perawatan dan pengobatan.

Pada penelitian ini, sebagian besar responden, yaitu 39 responden $(65,0 \%)$ menderita DM kurang dari 5 tahun. Bai, Chiou \& Chang (2009) menyatakan bahwa lama menderita yang lebih panjang membuat pasien dapat mempelajari perilaku merawat diri berdasarkan pengalaman yang sudah diperolehnya selama menjalani penyakit DM, sehingga pasien lebih mematuhi hal-hal yang harus dilakukan untuk mengelola penyakitnya $^{15}$. Sesuai dengan lama menderita yang lebih pendek tersebut, fenomena yang kami dapatkan di lapangan adalah sebagian besar responden tidak patuh dalam melakukan latihan fisik. Hasil dalam penelitian ini sejalan dengan penelitian serupa di RSUD Arjawinangun Kabupaten Cirebon yang menyatakan bahwa 28 dari 32 responden menderita DM kurang dari 5 tahun $^{16}$.

\section{Efikasi Diri}

Tabel 3. Distribusi Frekuensi Berdasarkan Efikasi Diri Pasien DM Tipe $2(\mathrm{n}=60)$

\begin{tabular}{ccc}
\hline Efikasi Diri & Frekuensi (f) & Persentase (\%) \\
\hline Baik & 21 & 35,0 \\
Kurang Baik & 39 & 65,0 \\
\hline Total & 60 & 100 \\
\hline
\end{tabular}

Dari tabel 3 didapatkan bahwa sebagian besar efikasi diri penderita DM tipe 2 kurang baik, yaitu sebanyak 39 responden $(65,0 \%)$. Hasil penelitian ini sama halnya dengan penelitian Isniyah (2018) yang menyatakan bahwa efikasi diri responden sebagian besar kurang baik ${ }^{17}$. 
Penelitian lain juga mendukung hasil tersebut yaitu Ningsih (2018) didapatkan bahwa efikasi diri responden DM kurang baik sebanyak 25 orang $(62,5 \%)^{18}$.

Hasil penelitian ini sesuai dengan teori yang menyatakan bahwa seseorang yang memiliki efikasi diri yang tinggi akan cenderung untuk memilih terlibat langsung dalam menjalankan suatu tugas, walaupun tugas tersebut adalah tugas yang sulit. Sebaliknya, seseorang yang memiliki efikasi diri yang rendah akan menjauhi tugastugas yang sulit karena mereka menganggapnya sebagai suatu beban ${ }^{19}$.

\section{Kepatuhan Melakukan Latihan Fisik}

Tabel 4. Distribusi Frekuensi Berdasarkan Kepatuhan Melakukan Latihan Fisik pada Pasien DM Tipe $2(\mathrm{n}=60)$

\begin{tabular}{ccc}
\hline $\begin{array}{c}\text { Kepatuhan } \\
\text { Melakukan } \\
\text { Latihan Fisik }\end{array}$ & Frekuensi (f) & Persentase (\%) \\
\hline Patuh & 22 & $36,7 \%$ \\
Tidak Patuh & 38 & $63.3 \%$ \\
\hline Total & 60 & $100 \%$ \\
\hline
\end{tabular}

Berdasarkan tabel 4, didapatkan bahwa sebagian besar penderita DM tipe 2 tidak patuh dalam melakukan latihan fisik, yaitu sebanyak 38 responden $(63,3 \%)$. Sejalan dengan penelitian Majid (2017), sebanyak 29 responden (53\%) tidak patuh dalam melaksanakan latihan fisik ${ }^{20}$. Penelitian lain juga memaparkan hasil yang serupa yaitu responden yang tidak patuh dalam melaksanakan latihan fisik sebanyak 33 orang $(75 \%)^{11}$.

Latihan fisik merupakan salah satu dari 4 pilar penatalaksanaan DM. Latihan fisik dapat meningkatkan sensitivitas insulin, memfasilitasi penyerapan glukosa, membantu mengontrol glukosa darah, membantu pengendalian tekanan darah, risiko penyakit kardiovaskular lain, serta menekan angka kematian dan meningkatkan kualitas hidup ${ }^{21}$. Kepatuhan sangat diperlukan dalam pelaksanaan latihan fisik. Kepatuhan berarti sejauh mana perilaku pasien sesuai dengan ketentuan yang diberikan oleh profesionel kesehatan ${ }^{22}$.

Fenomena yang ditemukan peneliti di lapangan, yaitu sebagian besar responden mengatakan bahwa mereka tidak melakukan latihan fisik dikarenakan cepat merasa lelah dan akibat usia mereka yang bertambah tua serta menurunnya status kesehatan, sesuai dengan data yang didapatkan peneliti bahwa rata-rata usia responden adalah 53,6 tahun. Sedangkan, bagi responden yang patuh dalam melaksanakan latihan fisik, mereka mengungkapkan bahwa dengan melakukan latihan fisik yang rutin membuat badan mereka lebih bugar dan sehat. Majid (2017) menyatakan bahwa salah satu faktor yang berhubungan dengan masih rendahnya latihan fisik pada penderita DM adalah karena faktor usia. Dalam penelitiannya, Madjid menunjukkan sebagian besar responden berusia 51 tahun keatas. Penurunan kemampuan fungsional tubuh responden seiring dengan memasuki masa lansia menjadi faktor penghambat dalam melakukan latihan fisik ${ }^{20}$.

\section{Hubungan Efikasi Diri dengan Kepatuhan Melakukan Latihan Fisik}

Tabel 5. Analisis Hubungan Efikasi Diri dengan Kepatuhan Melakukan Latihan Fisik pada Pasien DM Tipe $2(\mathrm{n}=60)$

\begin{tabular}{|c|c|c|c|c|c|c|}
\hline \multirow{3}{*}{$\begin{array}{c}\text { Efikasi } \\
\text { Diri }\end{array}$} & & $\begin{array}{r}\text { Ke } \\
\text { Telakı } \\
\end{array}$ & $\begin{array}{l}\text { patu } \\
\text { kan } \\
\text { Fisil } \\
\end{array}$ & $\begin{array}{l}\text { an } \\
\text { atihan }\end{array}$ & Total & \multirow[t]{3}{*}{ p-value } \\
\hline & \multicolumn{5}{|c|}{ Patuh TidakPatuh } & \\
\hline & $\mathbf{n}$ & $\%$ & $\mathbf{n}$ & $\%$ & n $\%$ & \\
\hline Baik & 15 & 71,4 & 6 & 28,6 & 21100 & \multirow{3}{*}{$<0,001$} \\
\hline Kurang & & & & & & \\
\hline Baik & 7 & 17,9 & 32 & 82,1 & 39100 & \\
\hline
\end{tabular}

Berdasarkan hasil penelitian hubungan efikasi diri dengan kepatuhan melakukan latihan fisik pada pasien DM tipe 2, didapatkan nilai $p$ value $<0.001$ yang berarti $\mathrm{H} 0$ ditolak, hal tersebut menyatakan bahwa ada hubungan antara efikasi diri dengan kepatuhan melakukan latihan fisik pada pasien DM tipe 2. Berdasarkan tabel 5, responden yang patuh dalam melakukan latihan fisik yaitu sebanyak 22 responden, 15 (71,4\%) diantaranya memiliki efikasi diri yang baik. Sementara, responden yang dinilai tidak patuh dalam melakukan latihan fisik yaitu sebanyak 38 responden, $32(82,1 \%)$ diantaranya memiliki efikasi diri yang kurang baik.

Hasil analisis pada tabel 5 menyatakan bahwa responden dengan efikasi diri yang baik cenderung memiliki perilaku yang patuh dalam melakanakan latihan fisik. Semakin baik efikasi diri seseorang, maka semakin patuh pula orang tersebut dalam melaksanakan latihan fisik yang diindikasikan. Berdasarkan teori Bandura (1997), dengan efikasi diri, kekuatan untuk usaha yang lebih besar mampu didapat. Semakin kuat 
perasaaan efikasi diri dan semakin besar ketekunan, maka semakin tinggi pula peluang keberhasilan atas kegiatan yang dipilih dan dilakukan ${ }^{8}$.

Hasil penelitian ini sejalan dengan penelitian ini yang dilakukan oleh Harjanto, Ekwantini, dan Cahyani (2015) dengan judul hubungan efikasi diri dengan kepatuhan pengelolaan DM tipe 2 di RSUP DR.Soeradji Tirtonegoro Klaten pada 70 responden, yang menyatakan bahwa terdapat hubungan yang signifikan antara efikasi diri dengan kepatuhan pengelolaan DM tipe 2 dengan nilai $\mathrm{p}=0.001$ dan $\mathrm{r}=0,36^{23}$.

Dari penelitian ini, didapati bahwa sebanyak 7 responden yang memiliki efikasi diri yang kurang baik tetapi patuh melaksanakan latihan fisik, disebabkan oleh faktor lamanya menderita DM, dimana sebagian besar responden menderita DM lebih dari 5 tahun.. Firdausi (2014) berpendapat bahwa pasien dengan durasi penyakit yang panjang cenderung lebih patuh daripada durasi yang pendek, hal ini dikarenakan pada durasi penyakit yang pendek pasien masih belum mengalami komplikasi jangka panjang sehingga pasien lebih santai dalam menjalankan terapi yang ditentukan. Lama seseorang menderita DM akan membuatnya memiliki banyak pengalaman terkait dengan masalah pada penyakit DM dan dengan pengalaman tersebut membuat penderita lebih patuh dalam mengelola atau menangani penyakitnya ${ }^{24}$.

\section{Keterbatasan Penelitian}

Keterbatasan dalam penelitian ini yaitu pada saat proses wawancara dengan responden berlangsung, jawaban responden terkadang berubah-ubah dan membuat penelti harus mengulang pertanyaan, sehingga kemungkinan bias informasi tidak dapat terhindarkan. Selain itu, peneliti tidak meneliti atau menilai faktor-faktor lain yang dapat mempengaruhi kepatuhan seperti, pemahaman tentang instruksi, dukungan keluarga, dan dukungan sosial.

\section{KESIMPULAN}

Penelitian ini menunjukkan adanya hubungan yang signifikan antara efikasi diri dengan kepatuhan melakukan latihan fisik pada pasien DM tipe 2. Diharapkan melalui penelitian ini, walaupun sebagian besar responden tidak mempunyai alat pemeriksa gula darah sendiri tetapi responden dapat memeriksakan gula darahnya secara teratur ke puskesmas, sehingga dapat patuh dalam menjalani latihan fisik yang telah diindikasikan.

\section{KEPUSTAKAAN}

1. American Diabetes Association (ADA). 2014. 'Diagnosis and Clasification of DM'. Diabetes Care 37(1): 580-590.

2. International Diabetes Federation (IDF). 2013. IDF Diabetes Atlas Sixth Edition.

3. Smeltzer, S.C \& Bare, B.G. 2008. Brunner \& Suddarth's Textbook of Medical Surgical Nursing. Philadelpia: Lippincott.

4. Sudoyo, A.W., Setiyohadi, B., Alwi, I., et al. 2006. Buku Ajar Ilmu Penyakit Dalam. Jakarta: Departemen Ilmu Penyakit Dalam FK UI

5. Riset Kesehatan Dasar (Riskesdas). 2013. Jakarta: Balitbang Kemenkes RI.

6. Perkumpulan Endokrinologi Indonesia (PERKENI). 2015. Konsensus Pengelolaan dan Pencegahan DM Tipe 2 di Indonesia 2015. Jakarta: PB PERKENI.

7. Suyono, S. 2006. Buku Ajar Ilmu Penyakit Dalam. Edisi 3. Jakarta: Pusat penerbit Departemen Penyakit Dalam FKUI.

8. Bandura, A. 1997. Self Efficacy: The Exercice of Control. New York: W. H. Freeman and Company.

9. Omrod, J. E. 2008. Psikologi Pendidikan Jilid I. Jakarta: Penerbit Erlangga.

10. Purwanti, L.E. 2014. Hubungan Motivasi dengan Efikasi Diri Pasien DM Tipe 2 dalam Melakukan Perawatan Kaki di Wilayah Kerja Puskesmas Ponorogo Utara. Ponorogo: Prodi DIII Keperawatan Fakultas Ilmu Kesehatan Universitas Muhammadiyah Ponorogo.

11. Khasanah, U. 2017. Hubungan Dukungan Keluarga dengan Tingkat Kepatuhan Melakukan Latihan Jasmani pada Penderita DM di Puskesmas Baki Sukoharjo. Surakarta: Program Studi S1 Keperawatan Fakultas Ilmu Kesehatan Universitas Muhammadiyah.

12. Pertiwi, I. 2015. Hubungan Dukungan Pasangan dan Efikasi Diri dengan Kepatuhan Menjalani Pengobatan pada Penderita DM Tipe II. Surakarta: Fakultas 
Psikologi Universitas Muhammadiyah Surakarta.

13. Tandra, H. 2008. Segala Sesuatu yang Harus Anda Ketahui tentang Diabetes. Jakarta: Gramedia Pustaka Utama.

14. Waspadji, S. 2015. DM: Mekanisme Dasar dan Pengelolaannya yang Rasional. Jakarta: FKUI.

15. Bai, Y.L., Chiou, C.P, \& Chang, Y.Y. 2009. 'Self Care Behaviour And Related Factor In Older People With Type 2 Diabetes'. Jurnal of Clinical Nursing 18:3308-3315.

16. Nurhayani, Y. 2016. Gambaran Efikasi Diri pada Pasien DM Tipe II di RSUD Arjawinangun Kabupaten Cirebon. Cirebon: Akademi Keperawatan Muhammadiyah Cirebon.

17. Isniyah, F. 2018. Hubungan Depresi dengan Efikasi Diri pada Pasien DM (DM) Tipe 2 di Wilayah Kerja Puskesmas Puger Kabupaten Jember. Jember: Program Studi Sarjana Keperawatan Fakultas Keperawatan Universitas Jember.

18. Ningsih, H.R. 2018. Hubungan Self Efficacy terhadap Kepatuhan Diit pada Penderita DM. Riau: Program Studi Ilmu Keperawatan Universitas Riau.

19. Friedman, H \& Schustack, W. 2008. Kepribadian Teori Klasik dan Riset Modern Jilid I. Jakrta: Erlangga.

20. Majid, T.T.I. 2017. Hubungan antara Dukungan Keluarga dengan Kepatuhan Melakukan Latihan Fisik pada Penderita DM di Puskesmas Gatak Sukoharjo.
Surakarta: Program Studi S1 Keperawatan Fakultas Ilmu Kesehatan Universitas Muhammadiyah Surakarta.

21. Kurniawan, A.A \& Wuryaningsih, Y.N. 2016. 'Rekomendasi Latihan Fisik untuk DM Tipe 2'. Berkala Ilmiah Kedokteran Duta Wacana 3(1).

22. Niven, N. 2012. Editor Monica Ester. Psikologi kesehatan: pengantar untuk perawat dan profesi kesehatan lain. Edisi 2. Jakarta: EGC.

23. Harjanto, T., Ekwantini, E. R, \& Cahyani, R.C. 2015. Hubungan Efikasi Diri dengan Kepatuhan Pengolahan DM Tipe 2 RSUP DR Soeradji Tirtonegoro Klaten. Electronic Theses \& Dissertations Gadjah Mada University.

24. Notoatmodjo, S. 2010. Pendidikan dan Perilaku Kesehatan. Jakarta: Rineka Cipta.

25. Bijl, J.V.D., Poelgeest-Eeltink, A.V \& Shortridge-Baggett, L.M. 1999. 'The Psychometric Properties of The Diabetes Management Self efficacy Scale for Patients with Type 2

26. DM'. Journal of Advanced Nursing 30(2): 352-359.

27. Ariani, Y. 2011. Hubungan antara Motivasi dengan Efikasi Diri Pasien DM Tipe 2 dalam Konteks Asuhan Keperawatan Di RSUP. H. Adam Malik Medan. Tesis. Depok: Magister Ilmu Keprawatan Kekhususan Keperawatan Medikal Bedah Fakultas Ilmu Keperawatan Universitas Indonesia.. 